\title{
AZ EU-CSATLAKOZÁS LEHETSÉGES ELŐNYEI ÉS HÁTRÁNYAI A MAGYAR AGRÁRGAZDASÁGRA
}

\author{
(Possible advantages and disadvantages of the Hungarian \\ integration into the EU on Hungarian agriculture)
}

\section{TÓTH LÁSZLÓ}

\section{Az Európa-politika atavizmusai mint az EU-bỏvités axiómái}

Az ún. európai, pontosabban a hivatalos uniós gondolkodást (és az ebből táplálkozó uniós politikát) az idő haladtával egyre érzékelhetỏbben és egyre erôteljesebben két atavizmus jellemzi. Az egyik úgy fogalmazható meg, hogy Európa csak egy paradigmán belül ismeri el a pluralizmust, de nem ismeri el a paradigmák pluralizmusát. Kissé egyszerübben, csak és kizárólag EU-paradigma van, Európa minden országának illetve régiójának - függetlenül attól, hogy az adott pillanatban és esetleg a jövőben az EU-n belül vagy kívül van-e - a megítélése, kezelése az EU-hoz való viszonyában történik. Európa jelene, még inkább jövője ezek szerint csak és kizárólag az Unió helyzetén értelmezhető.' Országoknak, régióknak az Unió politikai és egyre inkább az uniós bürokrácia követelményeihez kell (illik) igazodni, „kezelésưket" úgymond attól teszik függövé, hogy e kővetelményeknek mennyiben tudnak és akarnak megfelelni. Esetröl-esetre a diktátumok, az egyre kevésbé burkolt politikai és gazdasági zsarolás olyan megnyilvánulásait is tapasztaljuk, amelyeket a demokráciáról szóló frazeológia sem képes palástolni.

Európa középsó és keleti felében ehhez idomulva a nyomorúságból szabadulás kényszere, a nagy és egységes piac, a diszkrimináció megszünte, a hatékonyság, gażasági jólét és plurális demokrácia „mézesmadzagja” teszi megkivánttá, kívánatossá a mielóbbi hasonulást, befogadást, amit a kívülállók tülekedése, egymást legázoló igyekezete oly szépen példáz. Ezért halljuk nap mint nap itt és ott, hogy nincs politikai alternatíva az euroatlanti eszmével, a gyakorlatban pedig a csatlakozással szemben, még ha ennek vảrható és nyilvảnvaló problémáitól és hátrányaitól sokan "fáznak" is, és a csatlakozás időpontját igyekeznek homályos feltételek teljesítésétől fưggővé tenni, bizonytalan időre kitolni. Ma egyszerüen „szentségtörés” arról beszélni, hogy más müködő gazdasági modellek is léteznek, mint az uniós, amelyek más elveken építkeznek, ugyanakkor adott feltételek, körülmények között megfelelö hatékonyságot, gazdasági növekedést tudnak felmutatni.

$\mathrm{E}$ logikát következetesen érvényesítve, tovább gondolva nem bizonyítható az sem, hogy a ma az EU-n kívüliek számára nem létezik egy olyan modell, amely azt a feladatot, amelyet a kőzép- és kelet-európai régiók országaiban a modernizáció jelent, a mai uralkodó paradigmával szemben más alapokon jobban tudná szolgálni. 
A másik atavizmus - ami természetét tekintve politikai - lényege úgy foglalható öszsze, hogy Európa az egyetlen olyan kontinens, ahol hagyományosan minden ország ellenséges közvetlen szomszédaival. Mivel ez az integrációval ellentétes és destabilizáló hatású, még az integrálódás előtt fel kell számolni, amit nemzetkőzi jogi intézmények keretei kőzött, egyezményekben vagy más formákban deklarálni kell. Történelmi példaként a hagyományos német-francia ellenségeskedés megszủntetését, Dél-Tirol státusának rendezését emlitik. Az elsőszámú aspiránsok közül Törökország Görögországgal (és Ciprussal) szembeni, valamint Magyarország és szomszédai közötti ellenségeskedés megszủntetését tekintik a belépés minimálisan szükséges politikai feltételének. Ennek nemzetközi jogi egyezményekben történỏ deklarálását (legalábbis Magyarország és a szomszédai között), alapszerzódések megkoötését szorgalmazták illetve szorgalmazzák, miközben napnál világosabb, hogy itt szembekötősdi folyik, valójában az alapszerzỏdések nem alkalmasak arra a funkcióra (ti. az ellenséges érzületek és cselekvések megszüntetésére), amelyet szeretnének velük érvényre juttatni.

Ez a második atavizmus ugyancsak egy paradigma keretei közötti gondolkodást enged csupán meg számunkra, ami a közép-európai status quo minden áron való fenntartására épül, függetlenủl olyan realitásoktól, amelyek csupán az utóbbi nem egészen egy évtized során bekövetkeztek ebben a régióban. A balkáni új „pax americana” mintájára egy „pax europae” ily módon történő presszionálása azonban a régió etnikai, gazdasági, politikai-gazdasági sajátosságai kōvetkeztében igazából nem old meg semmit, legfeljebb a parázs a hamu alatt izzik tovább.

Mondhatná valaki, hogy a dolgozat címben jelolt témájától túlságosan messze esik, túlságosan átpolitizált az eddigi fejtegetés. Ennek azonban két érv is ellentmond. Az egyik, hogy az EU bóvítése, illetve az EU-csatlakozás alapvetỏen politikai, mégpedig nemzetközi politikai kérdés, politikai döntés (döntéssorozat) kérdése, vagyis bármennyire szeretnénk, bármennyire kényelmes lenne, nem kerülhető meg konkrét gazdasági problémák, gazdasági területek, így tehát az agrárszféra jövőjére vonatkozó vizsgálódások, elemzések tekintetében sem. A másik, hogy a jövỏ immanens természetéhez tartozik az alternativitảs, hiszen a jôvőre vonatkozóan nem létezik biztos, hanem kisebb vagy nagyobb valószínúség. Ha ezt a két atavizmust és a belölük következó paradigmákat fenntartás nélkủl elfogadjuk és kizárólag rájuk épitjük a jövöre vonatkozó döntéseket anélkül, hogy további alternativákat, variánsokat is megvizsgálnánk, nemcsak hibát követhetnénk el, hanem nem tennénk eleget annak a tudományos követelménynek sem, amely a tudomány egyik lényeges jellemzöjének a kételkedést tekinti. A középkorban az akkori tudomány a teológia szolgálója, ,ancilla theologiae" volt, saját legújabb kori tapasztalatunkból pedig ismerjük azt az állapotot, amikor „ancilla politicae"-t, a politika szolgálóját igyekeztek belöle csinálni. Nem lenne szerencsés sem az országra, sem személy szerint ránk kutatókra nézve, ha mindez más elöjelekkel megismétlódne ósdi beidegződéseken, átgondolásra, továbbfejlesztésre szoruló nézeteken nyugvó politika alapján.

\section{Az európai mezógazdaság „(love) sztorija”}

A nyugat-európai valamint a kỏzép-és kelet-európai országok viszonya az elmúlt 7-8 év során mind a retorika, mind a valóságos kapcsolatok szintjén többször is változott. Bár ezek a változások az általános udvariasság, a segítỏ szándék, a közeledés szúkségességének hangoztatása keretein belül maradtak, semmiképpen nem hagyhatók figyelmen kívül akkor, amikor az Európa egészének a jövőjével kapcsolatos lehetőségeket elemez- 
Tóth László : Az EU-csatlakozás lehetséges előnyei és hátrányai a magyar agrárgazdaságra Tér és Társadalom 10. évf. 1996/4. 15-26. p.

zúk. E változásokat kissé tréfásan egy olyan házassági elökészülethez hasonlíthatjuk, amit kezdetben a kokettálás és ismerkedés, a kapcsolatkeresés jellemez, ezt követi komolyabbra fordulva a dolog - a házassági szerződés körüli problémák tisztázása, amit befolyásol a rokonság, a külsó kötöttségek, körülmények alakulása is. Különösen jól érzékelhetỏ ez a folyamat a mezőgazdasággal kapcsolatos kérdések tekintetében.

$\mathrm{Az}$ ismerkedés illetve a kapcsolatkeresés egyik oldalról a közeledó partner „szalonképességének” megteremtésével kezdödött, amit a kívánatos partner a demokratikus intézmények kiépítésének, a piacgazdaságba való átmenetnek a követelményeiben fogalmazott meg. A gazdaság átalakításának alapjaként és elsőszámú követelményeként a privatizáció szükségességét jelölték meg, amely azután a mezógazdaság tekintetében kimondva-kimondatlanul a korábbi kollektivizált nagyüzemek megszüntetésének, a nyugat-európai családi típusú farmgazdaságok általánossá tételének céljában konkretizálódott. Mindez akkor, amikor kölcsönősen még igen keveset tudtak egymásról.

A konkrét kapcsolatok a külkereskedelem területén kezdtek intenzívvé válni. A KGST ősszeomlása és a keleti kereskedelem szétzilálódása miatt a kỏzeledni szándékozó országok megpróbálták élelmiszer-exportjukat azonnal Nyugat, mindenek elött az EU-országok piacaira konvertálni. Kiderült azonban - ami persze korábban sem volt titok, csak nem volt különösebb jelentősége -, hogy ami jó volt a Keletnek, a korábbi partnernek, az közel sem üti meg azt a mértéket minőség tekintetében, mint amit a nyugati fogyasztó kíván, továbbá, hogy a minőség az elérhető árat, ezáltal a megszerezhető profit nagyságát döntően meghatározza. A hirtelen megnövekedett importkínálat pedig első ijedtségükben arra késztette föként a mezőgazdasági felesleggel rendelkezó és saját belső piacait féltón nyugat-európai gazdaságokat illetve kormányokat, hogy a legkülönfélébb, hajuknál fogva elórángatott ürügyekkel korlátozzák ezt a hirtelen jött konkurenciát. ${ }^{2}$ A kelet- és kőzép-európai országok nyugati exportkényszere ezekben az elsó években abban a sajátos tendenciában fejeződött ki, hogy az export növekedése volumenben jelentösen meghaladta az értékbeni növekedést. Ehhez nem csupán a gyengébb minóség (mindenek előtt a csomagolás, feldolgozottság stb.) járult hozzá, hanem az exportálók részéról a hirtelen jelentkezó túlkínálat okozta árverseny is. Tulajdonképpen azóta kiderủlt, hogy az elózetes félelem és az ezzel járó propaganda és hisztériakeltés a keleti élelmiszer-dömpingtöl számos tekintetben megalapozatlan volt, a Közösség mezőgazdaságára, farmereire közel sem olyan veszélyes, mint amilyennek lefestették. Ezek a „görcsök" azonban lassan oldódnak, inkább csak a legutolsó egy-két évben kezdik a tagországok mezögazdasági szakemberei is reálisabban értékelni a helyzetet, amihez természetesen egyéb dolgok is kellettek.

Ezzel szemben viszont - tehát a Közösség agrárgazdaságainak keleti lehetőségeit illetỏen - viszonylag rövid idő alatt kiderült, hogy egy, a piacgazdasági konkurenciára felkészületlen, gyenge érdekérvényesítési készségú és piacgazdasági szempontból szabályozatlan, a hazai termelöket nem védö, mi tőbb, a liberalizációt mint valami a piacgazdasági átmenethez feltétlen hozzátartozó, szükséges „kelléket” feltétlenül elfogadó állami (kormányzati) magatartás kővetkeztében kiszolgáltatott mezógazdaságot a magas szinten támogatott és a fogyasztói társadalomban megtanult csomagolási, reklám- és PRtechnikákkal „felszerelt” nyugati élelmiszerekkel a belsố piacon is „,meg lehet szorongatni". Ezt a piacszerzést nagyban segítette, hogy az élelmiszeripar privatizálása során a külfơldi tóke által szerzett piaci pozíciók - melyek, mint látni fogjuk, egy külső mozzanatot is belevittek a kapcsolatokba - segítségével a megvásárolt kapacitások leállítása vagy a termelés csökkentése révén is könnyen elhelyezhetövé váltak a multik máshol gyártott termékei a keletkezett vákuumban, amelyek egyébként akadálytalanul, vámmen- 
tesen vagy a GATT által megengedett maximális vámnál jóval alacsonyabb vámszinten juthattak be az országba. A megvásárolt gyárak, azzemek, telephelyek pedig részben logisztikai illetve ellátó központként, raktárbázisként esetenként nagyobb hasznot hajtottak ủj tulajdonosaiknak, mintha termelés folyt volna bennük.

Amikor az érintett kormányzatok részben korrigálták az elkövetett „szarvashibát”, nagyrészt már késỏ volt: A szétzilálódott, termelési volumenét illetöen drasztikusan visszaesett, technikai színvonalában, szervezettségében leromlott mezögazdaság már nem volt képes talpra állni. A lakossági jövedelmek csökkenése a válságot még mélyítette és a mai napig mélyíti is. Mindezek követkcztében - mint azt a statisztikai adatok közismerten bizonyitják - egyrészt 1989-94 között Szlovénia és Románia kivételével a tíz volt szocialista országban ${ }^{3}$ reálér tékben csökkerłt a mezőgazdaság bruttó kibocsátása, másrészt Szłovákia kivételével ınezögazdasági termék és élelmiszer külkereskedelmi egyenlegük romlott, továbbá az EU-val folytatott mezőgazdasági termék és élelmiszer külkereskedelmi egyenlegük (az ősszehasonlítható országok esetében) Magyarország kivételével szufficitesböl deficitessé vált.

Hiába kötötte meg így a hat közép- és kelet-európai ország az Európai Unióval a Társulási Szerződést, a mezőgazdasági termékek és élelmiszerek kedvezményes bejuttatása a közösségi piacra lényegében kihasználatlan lehetőség maradt az említett okok következtében. Ez azonban már a (love) sztori folytatása.

\section{A házassági előkészületek buktatói - a mezőgazdasági integráció és regionalizáció}

A mezőgazdasági integráció köztudottan a kezdetektöl az egyik legneuralgikusabb problémája a Közősségnek. A mezőgazdasági közös piac csak jelentős fáziskéséssel és különleges szabályozással volt létrehozható, és azóta is állandó viták, ellentétek tárgyát képezi nem csupán a tagországok között, de a Közösség és a kivülállók között is. Ha ennek az okát keressük, azt kell látnunk, hogy a mezögazdaság integrációja nem elsődlegesen gazdasági, hanem sokkal inkább politikai érdekeken alapult és alapul ma is. A gazdasági és politikai érdekek diverzitásának magyarázatát abban találjuk meg, hogy az eltérő agroökológiai potenciál, továbbá a múlt, a tradíciók miatti tartós hatékonysági kủlönbségek regionálisan jelentősen eltérõ piaci poziciókat, piaci versenyhelyzeteket indukáltak ahhoz képest, mint amit a gazdaság más területein az egyéb közösségi érdekek indukáltak illetve diktáltak. A természetes agrár régióképzödés valójában soha nem volt "tekintettel" semmiféle integrációs határürra. Kezdetben ugyan volt egy külsődleges indoka a közös agrárpolitikának, nevezetesen, hogy az élelmiszerbiztonság egy nettó élelmiszer-importör integrációban olyan szabályozást kívánt, amely a külsỏ élelmiszer-függőséget perspektivikusan oldotta. A későbbiekben az integrációs agrárpolitikának azonban inkább demonstrativ szerepe vált hàngsúlyozottá, vagyis az, hogy az integráció fejlődése, erösödése egy területen, a gazdaság egy szektorában nem ,lóghat ki” az általános elvárások, az erősebb közös érdek diktálta tendenciák közül, amelyek olyan tartós jövedelmi különbségekhez vezettek volna a belsö piac liberalizálása következtében, amelyeket politikailag nem lehetett megengedni. A megoldás egy egyre bonyolultabb, átláthatatlanabb szabályozás és a mezógazdaság növekvö támogatása, amely hovatovább a Käzösség legnagyobb anyagi tơ hévé vált, ćs amelyet soha nem lehetett és lehet úgy elosztani, hogy az akár a nettó befizetőknek, akár a nettó kedvezményezetteknek osztatlan megelégedésére szolgált volna. 
Tóth László : Az EU-csatlakozás lehetséges elönyei és hátrányai a magyar agrárgazdaságra Tér és Társadalom 10. évf. 1996/4. 15-26. p.

TÉT 1996 - 4 Az EU-csatlakozás lehetséges elönyei és hátrányai a magyar... 19

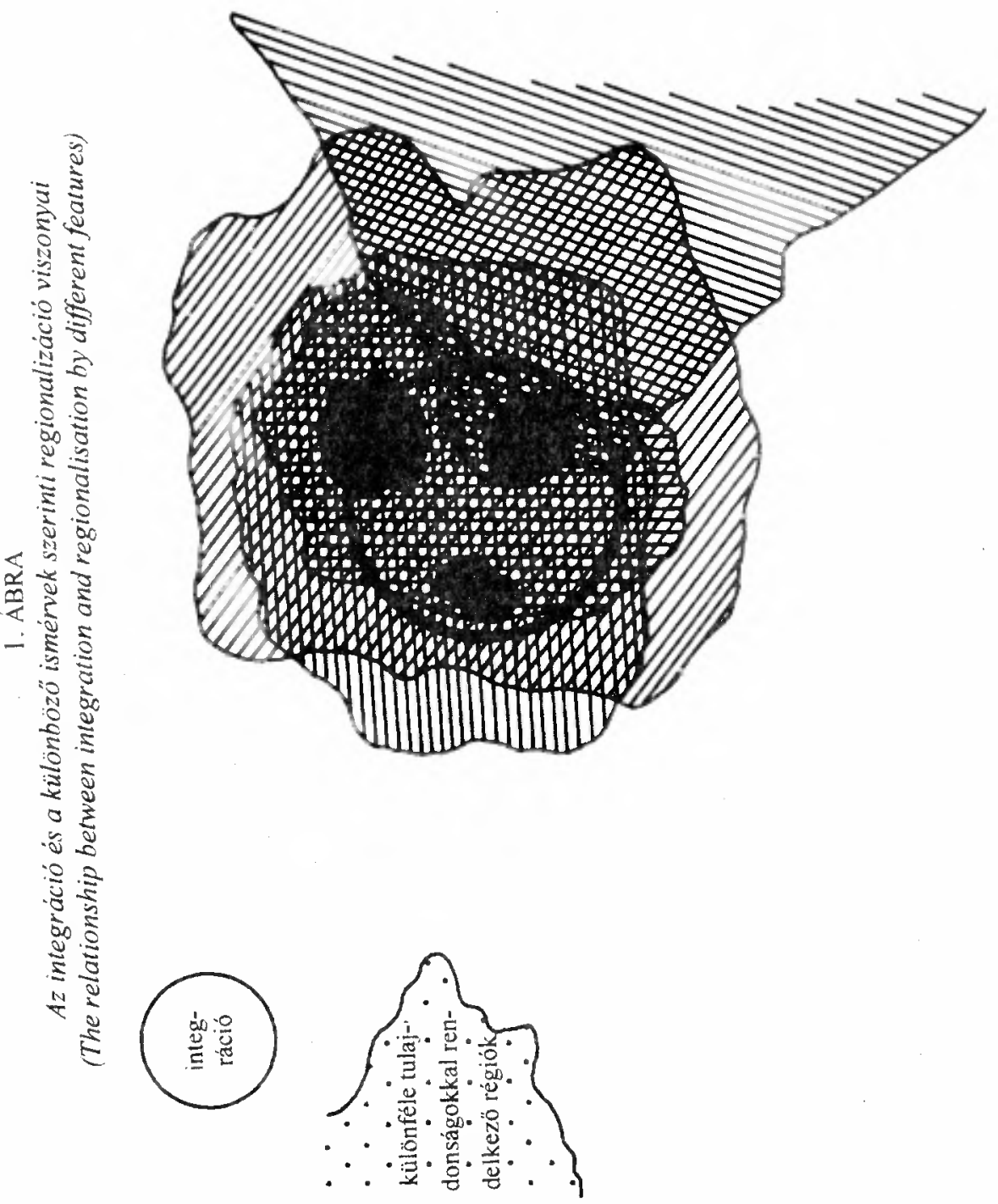


Az integráció és a regionalizáció ketiősségének tudható be az is, hogy a Közösség egyik legnehezebb problémája minden egyes bövülési-bövitési szakasz elött eddig is az volt, és ma is az, hogy a belépés előtt állók a külsőkkel szembeni protekcionizmus következtében inkább távolodnak a Közösségnek való megfeleléstól, semmint közelednének hozzá, hiszen az versenyképességüket, mezőgazdaságuk fejlesztését illetve a gazdagok belépés elötti alkalmazkodását gátolja, korlátozza.

Amikor a bővítés, a külsők csatlakozása konkrétan napirendre kerül, akár fejlettebb, gazdagabb, akár kevésbé fejlett, szegényebb országokról is van szó, a mezögazdaság harmonizációjóval egy elhúzódó, feszültségekkel terhes folyamat veszi kezdetét. A bövïlést követöen pedig - azz eddigi tapasztalatok szerint - felerösödik illetve megnö az ujjraelosztás kémyszere és mé:tèke. ami az integráció kohézióját mérsékli, ahelyett, hogy az ủjonnan belépők oldanák az egyébként is ineglévö problémákat. Természetesen könnyebb a problémákat kezelni a gazdag országok, mint a szegény aspiránsok esetében, de azt mindenképpen látnunk kell, hogy az elóbbiek gondjai sem az integráció általános erỏsítése irányába hatnak.

Valójában sem elméletileg, sem a gyakorlatban nem tisztázott, hogy az integráció milyen mértékig bövíthetô anélkül, hogy kohéziós ereje ne csökkenjen egy kritikus szint alá, vagy ne szünjön meg. Valószínünek csupán az látszik, hogy a CAP mint integrációs intézmény nagyon nehezen bir el a jelenleginél nagyobb "terhelést" a regionális kiterjesztés (elsỏsorban a mezỏgazdasági kiterjesztés) szempontjából. ${ }^{4}$

Ez is oka annak, hogy az aspiránsok társadalmi-gazdasági helyzetének, viszonyainak változtatására vonatkozóan számtalan - sokszor egymásnak ellentmondó, rögtönző - halogatónak tủnö csatlakozási követelményt jelölnek meg illetve javaslatot tesznek, amelyek nyilvánvalóan nélkülözik a mélyebb, egzaktabb megalapozottságot. ${ }^{5}$

\section{A „tágabb család" - az agribusiness globális viszonyai}

A mezőgazdasági integráció és regionalizáció viszonya azonban nemcsak önmagában értékelhető, hanem beágyazódik egy szélesebb kapcsolatrendszerbe, az agribusiness-be.

Világjelenség, hogy az élelmiszeripar és az élelmiszerkereskedelem a világon mindenütt a leginkább monopolizált ágazatok közé tartozik. Sỏt, e monopóliumok között a multinacionális vállalatok szerepe meghatározó. Ezek egy globális üzleti stratégia keretei között alakítják termelési és éttékesitési politikájukat, befektetési portfoliójukban a globális profitszempontokat érvényesítik. Ennek megfelelően a mezőgazdasági alapanyagok elsődleges feldolgozását oda telepítik, helyezik, ahol a mezőgazdasági termelés szempontjukból a legkedvezöbb. E tekintetben az agroökológiai potenciálból, az alacsonyabb bérekböl és egyéb járulékos költségek hiányából (pl. környezetvédelmi), az állami szabályozás különbőzőségeiböl stb.-ből fakađó előnyök érvényesítésére törekednek, majd a fogyasztók felé haladva, a növekvő feldolgozottsági foknak megfelelően az elsődlegesen feldolgozott alapanyagok továbbfeldolgozását a fejlettebb országokba illetve a globális marketing révén a kevésbé fejlettek megfeleló piaci szegmenseibe juttatják. Itt tehát sem az integráció, sem a regionalizáció nem elsỏdleges hatótényezö, azonban az integráció a komparativitásra hatást gyakorolhat abból következően, hogy a protekcionizmus minden esetben eltéríti a költségeket az enélkül egyébként kialakuló spontán nemzetközi munkamegosztás alapján, a komparativitásnak megfeleló ráforditásviszonyoktól. 
Tóth László : Az EU-csatlakozás lehetséges előnyei és hátrányai a magyar agrárgazdaságra Tér és Társadalom 10. évf. 1996/4. 15-26. p.

TÉT 1996 - 4 Az EU-csatlakozás lehetséges elönyei és hátrányai a magyar...

21

Mondhatni az elöbbivel analóg a mezőgazdasághoz input-oldalról kapcsolódó szektor helyzete és a mezőgazdaságot érintő hatása. Ha az iparnak van még erōsen monopolizált területe az élelmiszeriparon kívül, akkor ez minden bizonnyal az. Itt is a multinacionális vállalatok, valamint globális stratégiájuk határozza meg a mezőgazdasági tevékenységek feltételrendszerét nagymértékben attól függetlenül, hogy milyen integrációs illetve regionalizációs eröterek léteznek.

Képletesen szólva a mai körülmények között a multinacionális monopóliumok globális stratégiájába ágyazottan müködnek az integrált országok mezögazdaságai, amelyeket a közös agrárpolitika az eddig ismert és alkalmazott eszközeivel egyre kevésbé képes összehangolni. Az agribusiness multinacionális vállalatai globális stratégiája részeként illetve következményeként fogható fel viszont a nemzetközi szervezetek kereskedelem-liberalizációs törekvéseinek erösödése, amely arra irányul, hogy a protekcionizmus mérséklésével a nemzetközi agrár munkamegosztás racionálisabb lehessen, ezáltal a mezögazdasági termelés költségeinek csökkentésével az eddigieknél jobban érvényesíthetök legyenek a monopolista profitérdekek. Másképpen fogalmazva, a mezögazdaságot körülvevö multinacionális monopóliumok az integrációval szemben objektive inkább a természetes agroökológiai potenciálak azonosságán illetve különbözåségén alapuló regionalizációban érdekeltek. ${ }^{6}$

\section{2. ÁBRA}

A monopóliumak input és output oldali hatása az integrảlt mezögazdaságra (The effect of the monopolies on the integrated agriculture from input and output side)

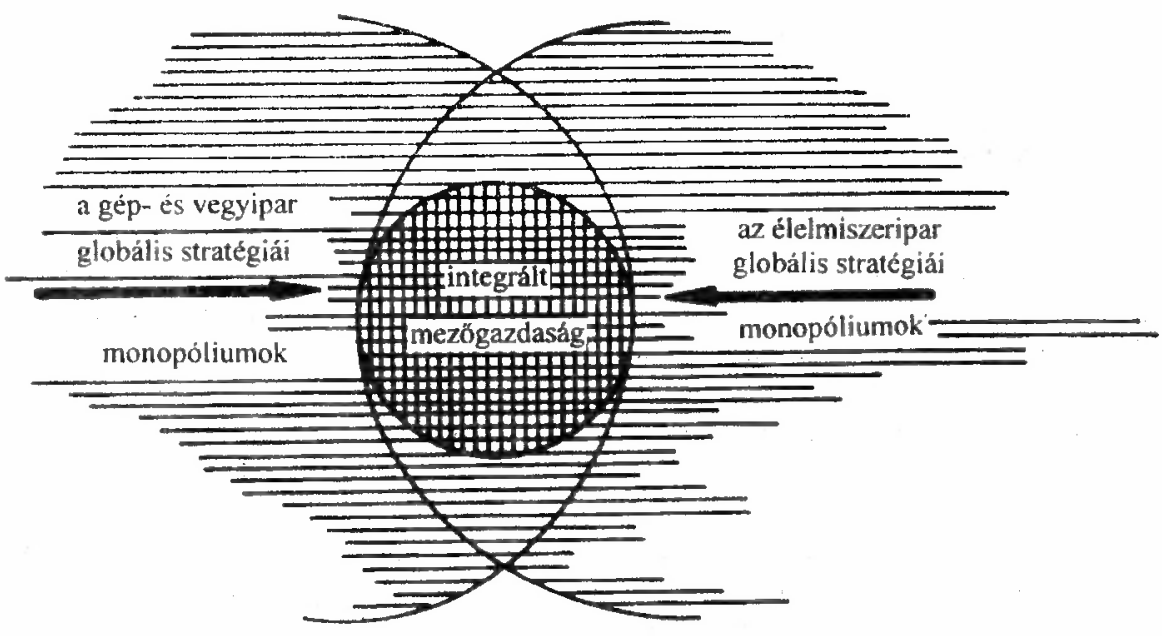

Ebböl a szempontból érdemelnek megkülönböztetett figyelmet azok az elképzelések és kezdeményezések, amelyek egyfelől az agrárpolitika „renacionalizációjára”, másfelöl az országhatárokon átnyúló ún. „eurorégiók” kialakitásával összefüggö kezdeményezések, amelyek itt-ott magának az integrảciónak a határait is átlépik, mint például az Alpok-Adria Eurorégió esetében. 
A globalizáció, az integráció és a regionalizáció természetének, összefüggéseinek és kölcsönhatásának valamint a mezögazdaságra gyakorolt hatásának, a mezőgazdaságban érvényesülỏ sajátosságainak tisztázatlansága valószinüleg nagyban hozzájárul ahhoz, hogy számtalan bizonytalanság, kétség, fals elképzelés, félelem, gyanakvás, másik oldalról indokolatlan optimizmus van a közös agrárpolitika jövöjével valamint az EU további bővítésének mezögazdaságot érintő következményeivel, hatásaival kapcsolatban. E kérdéseknek az újragondolása, alaposabb elemzése segithet ezek eloszlatásában és megfelelő megoldások megtalálásában illetve kimunkálásában.

A nagy általánosságok szintjén inkább csak az fogalmazódik meg, hogy milyen gazdasági elönyökkel járhat számunkra a csatlakozás. Közülük az áhitott 400 milliós piac (a többi potenciális csatlakozóval együttt), a tỏkehiány enyhítése, a technikai-technológiai felzárkózás, a modernizáció lehetősége keriil legtöbbször említésre. Kétségkívül vonzó, értelmes, perspektivikus elönyök ezek. Azonban arról hallgat a fáma (a hivatalos argumentálás), vagy legalábbis nem teszi egyértelmủvé, hogy a felemlegetett elönyök nem hullanak az ölünkbe, ezeknek ára van, illetve ára lesz a jövőben. Vagyis itt egy costbenefit relációról van szó, ahol a várható elönyökkel szembe kell állítani azokat a költségeket, amelyeket először a csatlakozásért, később a tagságért vállalnunk, fizetniink kell.

\section{Félelmek és veszélyek - miért tart a Közösség az agrárbővüléstől?}

Paradox módon sokkal többet tudunk azokról a fenntartásokról, félelmekről, amelyek az EU illetve egyes országai fogalmaznak meg már hosszabb ideje a lehetséges bővülést-bővítést illetỏen, mint az esetleg ránk hátrányos következményekrỏl. Nehéz lenne ennek a pontos okait megnevezni, sőt, talán nem is különösebben érdekes ez. Maga a jelenség a fontos.

Az Unió agrárpolitikusai, agrárspecialistái és agrárbürokratái évek óta veszik számba azokat a lehetséges veszélyeket és költségeket, amelyek az ún. „keleti bỏvülés” következtében leselkednek rájuk, különösképpen az agrárcsatlakozás következményeként. Mi több, már intézkedéseket, stratégiákat dolgoztak ki ezek kivédésére vagy legalábbis mérséklésére, amelyek egyik fontos állomása az országtanulmányok készítése volt az elmúlt évben, a másik pedig a közismert kérdöivek elkészitése és kitöltetése a csatlakozni szándékozókkal. Vagyis jól feltérképeztek bennünket, ami a csatlakozással kapcsolatos EU-tanulmányokból is érzékelhetőo. ${ }^{7}$ Sớt, eddigi magatartásukban, mint azt számtalan esetben érzékelhettük - minden ellentétes frazeológiával szemben -, már eddig is fellelhetö volt velünk kapcsolatos hosszú távú érdekeik felismerése és érvényesitése. $^{8}$

Milyen érdekek dominálnak valójában a közösségi magatartásban? Melyek a fö veszélyek, miböl származnak és mekkorák azok a költségek, amelyeket a „keleti bővülésbővítés" kapcsán megfogalmaznak illetve kalkulálnak? Induljunk ki a veszélyekből, mert ezekböl lehet levezetni a költségeket.

A veszélyek két csoportba sorolhatók. Az egyik csoport a piac oldaláról „leselkedik” az EU farmereire. A vámok nélküli piacon az olcsó keleti termékek konkurensei lesznek az eddigi belső piacon, a termelök elveszithetik piacaik egy részét. Ezt a veszélyt erösíti, hogy az Uruguay-forduló agrártámogatás-csökkentési kötelezettséget ír elő az Unió tagországai számára. Ezzel együtt a CAP-reform keretében csőkkenteni kell a mezőgazdasági termelést, hiszen teljesen irracionális az az eddigi gyakorlat, amely az adófizetók 
Tóth László : Az EU-csatlakozás lehetséges előnyei és hátrányai a magyar agrárgazdaságra

Tér és Társadalom 10. évf. 1996/4. 15-26. p.

TÉT 1996 * 4 Az EU-csatlakozás lehetséges elónyei és hátrányai a magyar...

zsebéböl finanszírozza az exportot. Ugyancsak piaci oldalon vélik megjelenni azt a veszélyt, amely a multinacionális feldolgozó cégek azon érdekéböl fakad, hogy bizonyos alapanyag-termelést - miután a privatizáció során jelentős feldolgozó kapacitásokat szereztek meg - áttelepítsenek költségtakarékosság okán a keleti országokba. Ez nemcsak piacvesztést, hanem munkahelyek elvesztését is eredményezheti, tehát fokozottan veszélyes.

Az emlegetett potenciális veszélyek másik csoportjába azokat sorolhatjuk, amelyek a költségek oldaláról "leselkednek” a már így is "túlterhelt", az Unió „szegényházába” tartozó déli tagok és Írország mezőgazdaságának finanszírozása miatt, amelyek mint nettó kedvezményezettek a leginkább igénybe veszik a közös alapokat. Rémisztö összegek röppennek fel időnként arra vonatkozóan, hogy különféle feltételek mellett, különféle szcenáriók szerint mibe fog kerülni, illetve mibe kerülhet a mai tagoknak a bóvülés után a közös agrárpolitika (CAP).

A veszélyek elháritására, a prognosztizált költségek elkerülésére alapvetően kettős stratégia körvonalazódik az EU agrárpoltikáját meghatározó körökben. Egyfelól a CAPreform felgyorsítása az ún. MacSharry-reform szellemében, hogy ezáltal megvalósuljon a jelenlegi EU-tagországok mezőgazdasága versenyképességének fokozása a hatékonyság nővelése révén, amelynek dőntő mozzanata a támogatás jellegú kifizetések és a termelés közötti kapcsolat megszüntetése. A másik vetületben ez azt jelenti, hogy a termeléshez kötött támogatásokkal szemben a közvetlen jövedelemtámogatásokra, illetve a vidékfejlesztéshez kapcsolódó támogatásokra kell a hangsúlyt helyezni. Mindebböl az is következik, hogy a versenyszférában a mostaninál koncentráltabb üzemi struktúra, nagyobb átlagos ủzemméret kialakítása a cél, a jelenleginél is kisebb agrárnépességgel. Így lehetóvé válik már viszonylag rövidebb távon is az árak csőkkentése (föként a gabona, a tej és a marhahús esetében), amit egy átmeneti időszakban kompenzációval hidalnak át. Eközben a nem föfoglalkozású üzemek jövedelem-kiegészítö szerepüket részben az önellátásban, részben a helyi, lokális piacokon megtartják.

\section{A csatlakozás lehetséges következményei felölünk nézve}

Mielött megpróbáljuk a csatlakozás számunkra lehetséges következményeit számba venni, talán nem felesleges egy apró, evidenciának tartott, azonban sokszor elfelejtödő tudományelméleti megjegyzést tennünk. Ez arra vonatkozik, hogy szükségszerüen megkülönböztetendỏ egymástól a prekoncepció és a hipotézis. A kettőt ugyanis gyakran összekeverik egymással. A prekoncepció valójában olyan előfeltevés, amelyet minden áron, minden lehetséges (ál-) tudományos eszközzel bizonyítani igyekeznek, amelynek bizonyításához akár meghamisitanak, elhallgatnak tényeket, vagy féligazságokat, részigazságokat sorakoztatnak fel. Ezzel szemben a hipotézis olyan feltételezés, amelyet az egzakt, korrekt tudományos vizsgálódás vagy igazol, vagy sem.

E rövid megjegyzésre azért került sor, mert szükséges leszögezni, hogy nincs semmiféle ab ovo fenntartásunk, még kevésbé elutasitásunk az EU-hoz való csatlakozást illetően. Hipotézisünk azonban az, hogy az EU integráció jövője nem irható le a jelenlegi viszonyok és vélekedések sematikus extrapolációjával, vagyis az EU fejlōdése, az integráció folyamata - beleértve a keleti bövülést is - nem feltétlenül lesz "töretlen", továbbá, hogy az EU-csatlakozásnak a magyar gazdaságra, ezen belül a mezógazdaságra pozitiv és negativ hatásai egyaránt lehetnek, vagyis a csatlakozás egyidejúleg járhat 
elónyökkel és hátrányokkal is. Kérdés, hogy melyek lesznek (lehetnek) a dominánsak, továbbá a pusztán elvi, elméleti lehetöségủek, illetve valóságosak, ténylegesen hatók?

A csatlakozás leggyakoribb várható pozitiv következményeként a protekcionizmus nélküli piacra történö bejutást, a kibővualt EU már aposztrofált, mintegy 400 milliós piacát fogalmazzák meg azok, akik az integráció, a csatlakozás feltétlen hívei. Ez azonban valójában inkább teoretikus, semmint reális, valóságos jövóbeni lehetőség. Az tudniillik soha, sehol nem fogalmazódott meg az EU részéröl, hogy a jelenlegi tagállamok saját piacaikat, vagy annak akár valamely kis szegmensét is önkéntesen, puszta jószándékból átadnák nekünk. Maximum azt inondják - és ez saját érdekeik alapján még csak nem is nehezményezhetô -, hogy a túltermelést, a drága, ráfizetéses exportot építik le. Nem is titkolják, hogy nem szeretnék piacaikat átengedni nekünk. Fischler, az EU mezőgazdasági föbiztosa éppen Budapesten jelentette ki, hogy nekünk a keleti piacokra kell alapoznunk, nem várhatjuk el, hogy agrárexportunkat az EU-piacokon növeljük. Ez implicite azért azt is jelenti, hogy bár a harmonizációt, annak minden költségével megkövetelik, felvételünk feltételeként szabják, a Közösségi piacokon létezö versenyböl szándékaik szerint kirekesztenének bennünket. ${ }^{9}$

Itt kapcsolható be a következŏ momentum az elemzésbe. A harmonizáció elófeltétele, alapja végső soron a mai sok tekintetben kaotikus, válságban lévő mezőgazdaság, agrárgazdaság „rendbetétele”. Más szóval a csatlakozás feltétele egy versenyképes, korszerú, hatékony agrárgazdaság. Ennek megteremtése azonban drága, tőkeigényes, amire a mai nemzetgazdaság, különösképpen pẹdig a mezögazdaság a forrásokat öneróből nem tudja biztosítani. Nyilvánvaló az ellentmondás a cél-és eszközoldal között, amelynek a feloldása ma nehezen látható.

Logikailag ezen a ponton vethetô fel a mezőgazdaság támogatásának kérdése. Az EU agrárszakértói, még inkább agrárpolitikusai óva intenek bennünket attól, hogy növeljük a mezőgazdaság támogatását, mert ez rontja a hatékonyság növelését, a versenyképesség fokozását, ami pedig az EU-lét feltétele. Kifejezetten rossz néven veszik, dühödten emlegetik, hogy az 1991-es mélyponthoz képest a támogatások (különösképpen az exporttámogatások) újra nőttek az elmúlt pár évben. A támogatások növelésével szembeni érvek sorában elökelö helyet foglal el annak argumentálása, hogy az EU-ban is csökkentik a támogatásokat, amit egyébként a GATT illetve WTO kötelező érvénnyel ír elö. Csakhogy van itt megint egy kis „bibi”. Nevezetesen az, hogy PSE-ben kifejezve a mi támogatásunk még most sem éri el egyfelöl az EU-átlag felét, továbbá, hogy a támogatások ezen szintje megközelítően sem tesz lehetővé akkora jövedelem-szerzést, mint az EU-átlag. Ebből azután egyenesen következik, hogy még ilyen támogatottság mellett sem képes a mezỏgazdaság arra a felhalmozásra, amit az a bizonyos, csatlakozáshoz sziikséges fejlettségi, termelékenységi, versenyképességi szint megkívánna! Nem beszélve arról, hogy az EU agrártámogatása egyre kevésbé mérhető a hagyományos módon, a PSE révén, mert a támogatások növekvő hányada olyan közvetlen jövedelemtámogatás, amely kívül esik ennek körén. Vagyis az a helyzet, amelybe a Közösség igyekszik bepréselni bennünket, az a ,játéktér", amelyet a csatlakozás kapcsán számunkra kijelölnek az agrárszférában, a vázolt összefüggésben típikusan a „22-es csapdảja”.

Végezetül még egy olyan extrapolálható hatást említünk meg, amely meghatározó jelentőségủ a jövő szempontjából. Ha a hatékonyságot, a versenyképességet mint elérendó célt határozzuk meg a csatlakozás előfeltételeként, számolni kell azzal, hogy a mezőgazdasági foglalkoztatottság eróteljesen csőkkenni fog. Ez a csökkenés időben behatárolt, ha a csatlakozás idejét az ezredfordulóra vagy az azt követő egy-két évre tesszük. Viszonylag jól megbecsülhető különböző termelékenységi szintek elérése ese- 
Tóth László : Az EU-csatlakozás lehetséges előnyei és hátrányai a magyar agrárgazdaságra

Tér és Társadalom 10. évf. 1996/4. 15-26. p.

tén a felszabaduló munkaerö száma, amely akár több százezres nagyságrendủ is lehet ebben a mondjuk hat-tíz éves periódusban. A gazdaság jelenlegi állapota mellett még a legoptimistább feltételezések szerint sem lehetséges olyan növekedés ebben az időszakban, amely képes lenne ezt a munkaerő-felesleget más nemzetgazdasági területeken felszívni. A munkaerö-felesleget legfeljebb mérsékelheti, ha a gazdasági növekedés beindulásával a belső élelmiszer-kereslet növekszik. Ez azonban kettős vonatkozásban is hipotetikus. Egyrészt hipotetikus a gazdasági növekedés beindulása, másrészt az is, hogy a megnövekedett kereslet a magyar termékekre irányul-e, hiszen köztudottan a hazai piacon is egyre nagyobb részarányban vannak jelen a jobban támogatott, emiatt és más tényezőkböl következöen is versenyképesebb közös piaci termékek.

Összefoglalva tehát két dologra szerettem volna felhívni a figyelmet egy adott, számunkra különösen fontos nemzetgazdasági szegmens példáján. Egyrészt közel sem biztos, hogy az EU fejlődése a politikai deklarációk ellenére azt a lineáris trendet kőveti, amit ma sokan feltételeznek, és amelyhez mint etalonhoz próbál a hivatalos politika minden erővel igazodni. El kellene gondolkodni azon, milyen egyéb, reális alternativák lehetségesek az EU, vagy még inkább Európa jövője tekintetében, és ezekhez az alternatívákhoz is célszerủ lenne stratégiákat illeszteni. Másrészt le kellene vetkőzni azokat az egyoldalúságokat, amelyek a csatlakozás várható pozitiv hatásait abszolutizálják. A várható, elöre jelezhető pozitív és negatív hatások szembeállításával mérlegelhető a csatlakozás igenlése, ne adj' Isten elvetése. Ezt a mérlegelést elmulasztani nem egyszerủen hiba, de kifejezetten bủn lenne a jövő generációkkal szemben.

\section{Jegyzetek}

I E felfogás tipikus példáját találhatjuk Enders, A. - Wonnacott, R. J.: The Liberalisation of East-West European Trade: Hubs, Spokes and Further Complications c. tanulmányában. In: The World Economy, Volume 19, No 3, May 1996, 353-272. o.

2 Elég, ha arra emlékeztetunk, hogy Olaszország azért tiltotta meg egy idöben a juh illetve a juhhús bevitelét Magyarországról állategészségùgyi szempontokra hivatkozva, mert néhány más országban és Olaszországban (!) járványos száj- és körơmfảjás volt!

3 CEFTA országok, Litvảnia, Lettország, Észtország.

4 Ezen nem segít Maastricht sem, hiszen - mint azt egyre többen állítják - itt is a politikai szempontok deklarativ célú elsödlegessége az, ami a végrehajtást nehezíti és a kơzósségi kohéziót gyengíti. A Maastrichti Egyezménynek mások által is megfogalmazottan talán éppen az a legnagyobb veszélye, hogy a politikát sokkal inkább ơncélként tételezi, nem pedig olyan eszkơzként kezeli, amely a gazdaság érdekében kerül alkalmazásra. Az ilyen "megoldások" - mint azt Közép-és Kelet-Európában tudjuk - a bürokrácia túlburjảnzásának, a centralizált irányitásnak a melegágyai, ami elóbb-utóbb a gazdasági érdekek háttérbe szorításával, azok csorbításával jár, a gazdasági hatékonyságot pedig rontja.

5 A, "kifelé terelés", az, elháritó" magatartás ilyen jellegzetes megnyilvánulása. mondhatni ,gyöngyszeme". hogy egyre gyakrabban hallani, hogy a kơzép- és kelet-európai belépni szándékozók számára az igazi, potenciális, perspektivikus piac a Távol-Kelet lehet, mert az ottani újonnan iparosodott országok az ezredfordulót követően nem lesznek képesek magukat élelmiszerrel ellátni. Nem beszélve arról, hogy ezek a prognózisok mennyire megbizhatók vagy sem, az mindenképpen elgondolkodtató, hogy a potenciális, de konkrétan nem meghatározott konkurenciától való félelem mennyire erös. Hiszen a fejlett kơzösségi mezógazdaság számára ennek a piacnak legalább annyira, ha nem jobban vonzónak kellene lennie, mint a számtalan sebbỏl vérzó, válsággal kủszkơdö, abból kilábalni nagyon nehezen tudó kơzép- és keleteurópaiaknak.

6 Ezt erősíti az, a fogyasztás internacionalizálódásával, uniformizálódásával egyuttt járó folyamat, amelyet természetesen éppen az emlitett monopóliumok is elösegítenek. A különféle közỏsségi szabványok. élelmiszerekre vonatkozó elöirások stb. a felszinen úgy tünhetnek, mint tisztán integrációs jelenségek, azonban könnyen belátható, hogy legalább ennyire a monopóliumok globális érdekeit szolgálják.

7 Lásd többek között: S. Tangenmann and T. Josling: Pre-accession agricultural policies for Central Europe and the European Union, Study commissioned by DG I, European Commission, 1994; Agricultural 
Situation and Prospects in the Central and Eastern European Countries. Summary Report, EU Commission Directorat-General for Agriculture, Working Document, 1995; White Paper on the implication for the CAP of integrating the Central and East European countries into the European Union, EU Agriculture Council, 1996.

8 Rendkívül tanulságos pélđául a PHARE-program keretében nyújtott eddigi EU-segélyek elemzése, amely egyértelmüen bizonyitja, hogy egyfelöl a fortások „visszaszivása" 1990-93 közott szolid becslés szerint is legalább 50\%-os volt, továbbá a támogatott célok kivétel nélkül az EU érdekeit tartották szem elótt, mert egyrészt olyan teruletekre irányultak, ,...amelyek elhanyagolása az EU számára is negatív hatással járna, például az állategészségügy vagy a nővényegészségügy kérđése, a jărványmegelőzés vagy a környezetvédelem. Másrészt segítségét azokra a területekre koncentrálja, amelyek fejlesztése saját gazdasági céljai megvalósítását szolgálják: ilyenck pélđául az infrastruktúra, a kơzlekedés, az energiaellátás fejlesztése... Szintén ebbe a kategóriába tartoznak azok a teruletek, amelyek tármogatása az EU információval való ellátáát szolgálja... (Egyes kimutatások szerint minden I márkanyi segély mintegy 5 márkányi exportot generál!" - mármint a segélynyújtórak - T. L.) Kiss Judit: Segélycsekélység - A PHARE és a magyar agrárium, Figyelö, 1996. május 16. 52-54. o.

9 Nem tartozik a szủken vett elemzés körébe, hogy milyen problémák vannak a keleti piacok tekintetében, azt azonban mindenki tuđja, hogy nem táplálhatók kủlönösebb illúziók e piacok stabílitását, fizetőképességét, rizikómentességét illetően.

\section{POSSIBLE ADVANTAGES AND DISADVANTAGES OF THE HUNGARIAN INTEGRATION INTO THE EU ON HUNGARIAN AGRICULTURE}

\section{LẢSZLÓ TÓTH}

The transitions following the turn of the 1980s-1990s raised the issues about the future of Europe in a new light. The "European idea", the expansion of the EU was accompanied with the task of a possible Eastern expansion. The ideas concerning the future, however, are many times one-sided in their attitude and they are based on political and ideological notions, reflexes rather than reality. Still, they do not even meet the criteria of alternativity.

The issues and problems of the future of the integration are especially serious in matters of agriculture. The agriculture of the Community has been known from the beginning as one of the most problematic fields of the integration, which, as the author of the essay sees, is the consequence of the characteristic contradiction of integration and regionalisation and which seems to be justified by all expansions/accessions so far. The future of the EU as whole and the chances of accession for those who are new applicants will largely be determined by the future of the common agricultural policy.

Based on the experiences of the past 7-8 years it is evident that we have to get rid of several illusions and fears that emerged in connection with the future of the European agriculture. There is only one way to do it: Besides forecasting the possible changes of the common agricultural policy, we will have to explore the favourable and unfavourable consequences of the expected accession in order to be able to work out adequate strategies.

The future and possible effects of the agrarian integration are of special importance for Hungary. The ideas outlined in the essay are meant to provide some theoretical support for the creation of the right strategies. 